Itinera Spiritualia

$\mathrm{X} \cdot 2017 \cdot 41-54$

\title{
KOMENTARZ TEOLOGICZNY DO DWÓCH NIEPUBLIKOWANYCH W POLSCE WIERSZY ŚW. ELŻBIETY OD TRÓJCY ŚWIĘTEJ, ODNALEZIONYCH I OPISANYCH PRZEZ CONRADA DE MEESTERA OCD
}

Niniejsze opracowanie nawiązuje bezpośrednio do artykułu Conrada De Meestera $\mathrm{OCD}_{z} 2000$ roku zatytułowanego Deux poésies inédites (Dwa niepublikowane wiersze $)^{1}$. Jest to ten sam karmelita, który w latach 1979-1980 przygotował do druku w języku francuskim (Euvres complètes ${ }^{2}$ św. Elżbiety od Trójcy (wówczas kandydatki na ołtarze). We wspomnianym artykule opublikował on odnalezione później dwa nieznane wiersze św. Elżbiety i opatrzył je komentarzem ${ }^{3}$. Kiedy w 2005 roku przygotowywano pierwsze polskie wydanie jej Pism wszystkich, oparto się na francuskiej edycji książkowej" dlatego wiersze później znalezione nie zostały dołączone.

W artykule o. De Meestera zostały one oznaczone - zgodnie z zasadami przyjętymi we francuskim wydaniu krytycznym - skrótami ${ }^{5} \mathrm{P} 72$ bis i P 72 ter. Powstały one w młodych latach Elżbiety, tuż przed jej wstąpieniem do klasztoru,

Zob. C. De Meester, Deux poésies inédites, „Carmel” 2000, nr 2, s. 33-44.

2 Pierwsze wydanie było przygotowane w trzech tomach: ÉLISABETH DE LA TRINITÉ, J'ai trouvé Dieu. CEuvres complètes, t. I/A, I/B, II, Paris 1979-1980; kolejne, w jednym woluminie, ukazało się pod skróconym tytułem: ÉLISABETH DE LA TrinitÉ, CEuvres complètes, Paris 1996 (dalej: (Euvres)

3 Znajdowały się one w karmelu we Flavignerot, w paczce $\mathrm{z}$ planami konstrukcyjnymi dawnego klasztoru w Dijon; C. De MeEster, Deux poésies inédites, s. 33

4 EıżBieta oD Trójcy Świętej, Pisma wszystkie, t. I-III, Kraków 2005. Warto dodać, że nawet kolejne francuskie opracowanie z 2007 roku (ÉLISABETH dE LA TRINITÉ, CEuvres complètes, Paris 2007) nie zostało uzupełnione wierszami P 72 bis i P 72 ter.

5 Zgodnie $\mathrm{z}$ polskim wydaniem, w którym numeracja francuska została zmieniona, wiersze te należałoby oznaczyć konsekwentnie symbolami P 73 bis i P 73 ter. Jednakże w niniejszym artykule używany będzie zapis francuski, tzn. P 72 bis oraz $P 72$ ter. 
pod koniec 1899 roku; pierwszy (P 72 bis) w dniu 23 listopada, drugi (P 72 ter) 16 grudnia. Pod względem literackim - twierdzi o. De Meester - nie mają one wielkiej wartości; brakuje w nich głębokiej symboliki, a rymy są bardzo proste. Elżbieta Catez miała niewielkie wykształcenie szkolne, ale bardzo lubiła wyrażać swoje uczucia, pisząc poezje ${ }^{6}$. Jeśli czytelnik nie skupi się na ubóstwie i zwyczajności słów, dostrzeże głębię doświadczenia mistycznego dziewiętnastolatki. $\mathrm{Z}$ tego też powodu w niniejszym wprowadzeniu proponuje się dosłowne tłumaczenie obu wierszy $-z$ konieczności pomijające troskę o oddanie rytmu czy rymów. Pozwoli to precyzyjniej przedstawić główne myśli teologiczne zawarte w tych utworach.

\section{Pragnienie życia z Chrystusem w klauzurze - wiersz P 72 bis}

Niewielki, składający się z trzynastu strof utwór P 72 bis został napisany przez Elżbietę Catez, gdy oczekiwała na wstąpienie do znajdującego się w sąsiedztwie jej domu karmelu w Dijon. Już w wieku czternastu lat poczuła w czasie modlitwy pragnienie powierzenia się Bogu i wybrania Go na swojego oblubieńca poprzez ślub dziewictwa; gdy to uczyniła, pewnego dnia niedługo potem - po przyjęciu komunii św. - wydało jej się, że w jej duszy zostało wypowiedziane słowo „Karmel”. Od tego momentu myślała intensywnie o życiu zakonnym w karmelitańskiej klauzurze i czekała na chwilę, kiedy to pragnienie będzie się mogło zrealizować . Wtedy tė̇ zaczęła pisać wiersze.

Czas oczekiwania na wstąpienie do karmelu był dla Elżbiety okresem przyjmowania łask, ale też trudu i cierpienia. Było to spowodowane tym, że kształtowała swoje serce na serce oblubienicy Chrystusa, a jednocześnie uczestniczyła dalej w zwykłym życiu towarzyskim. Jej matka starała się przygotować ją do wyjścia za mąż. Gdy Elżbieta wyjawiła jej swoje pragnienie, matka nakazała jej poczekać do dwudziestego pierwszego roku życia. Elżbieta zgodziła się na to. Z pewnością nie uczyniła tak dlatego, że bała się przyjąć stanowczą postawę ( w dzieciństwie bywała impulsywna i często starała się postawić na swoim). Pracując nad charakterem, pragnęla we wszystkim dostrzegać wolę Bożą i wszystko przyjmować w tym duchu ${ }^{8}$. Wydaje się również, że chciała, by jej mama - obawiająca się, że córka popełni błąd w wyborze życiowej drogi - odnalazła spokój serca i nabrała pewności, że rzeczywiście Bóg woła Elżbietę do klauzury.

Zob. C. De Merster, Deux poésies inédites, s. 34.

Zob. La Servante de Dieu. Elisabeth de la Trinité. 1880-1906. Souvenirs, Paris 1946, s. 18-19.

(Dalej: Souvenirs).

8 Por. A.M. SiCARI, Elisabetta della Trinità. Un'esistenza teologica, Roma $2000^{2}$, s. 57 . Ta uległa postawa Elżbiety mogła stać się przeszkodą w procesie beatyfikacyjnym i kanonizacyjnym; na szczęście tak się nie stało i odczytano jednoznacznie oczekiwanie na zgodę matki jako wyraz miłości do Boga, który posługuje się ludźmi. 
Tymczasem więc oczekiwanie na wstąpienie do karmelu Elżbieta przeżywała jako czas jej narzeczeństwa z Chrystusem. Czytała Dzieje duszy Teresy $\mathrm{z}$ Lisieux oraz Drogę doskonałości św. Teresy z Awili ${ }^{10}$. Lektury te pozwoliły jej pojąć głębiej łaskę oblubieńczej miłości z Bogiem oraz misterium zamieszkania Boga w człowieku. Wzbudziły pragnienie oderwania się od wszystkiego, co odciąga od tej Bożej rzeczywistości, oraz wyrażania miłości Chrystusowi poprzez ofiarowywanie Mu swoich cierpien - dla zbawienia siebie i innych ${ }^{11}$.

Wszystko to tworzy tło dalsze powstania wiersza P 72 bis. Kontekst bliższy stanowiła uroczystość obłóczyn, której Elżbieta była świadkiem. 23 listopada 1899 roku w karmelu w Dijon, podczas liturgii prowadzonej przez biskupa Le Nordez, przyjęła habit s. Magdalena od Jezusa. Conrad De Meester zwraca uwagę, że część główną wiersza stanowią strofy centralne (4-9), skierowane bezpośrednio do Chrystusa ${ }^{12}$. Pozostałe tworzą swego rodzaju klamrę osadzającą mistyczną rozmowę w konkretnym miejscu i czasie. Jest to odpowiedni moment, by zapoznać się z treścią tego utworu ${ }^{13}$ :

\section{Souvenir du 23 novembre 1899}

1. Ôma Passion, mon Amour, Jésus Mon divin Époux, que jaurais voulu Pouvoir comme cette heureuse fille Disparaître derrière la grille.

2. Durant la belle cérémonie, Ô mon bien cher Trésor, ô ma Vie, Toi qui me donnes ma vocation Seul tu vis toute mon émotion.

3. Ah! je pensais au bienheureux jour Où je quitterai celles que jaime Pour te consoler, mon Bien suprême, Et te rendre un peu de ton amour.

\section{Pamiątka 23 listopada 1899 roku}

1. O moja Pasjo, ma Miłości, Jezu, Mój Boży Oblubieńcu, jakżebym chciała Móc jak ta szczęśliwa dziewczyna Zniknąć za tymi kratami.

2. Podczas tej pięknej ceremonii, O mój najdroższy Skarbie, moje Życie, Ty, który mi dajesz me powołanie, Tylko Ty widzisz całe moje wzruszenie.

3. Ach! Myślałam o błogosławionym dniu, Kiedy opuszczę tych, których kocham, By Cię pocieszyć, moje Dobro najwyższe, I by oddać Ci trochę Twojej miłości.

\footnotetext{
9 Por. tamże, s. 65.

10 Zob. Élisabeth de la Trinité, Euvres complètes, Paris $1996^{2}$, s. 445, 1069; M.-M., Philipon, Élisabeth de la Trinité,w: Dictionnaire de Spiritualité. Ascétique et Mystique. Doctrine et Histoire, red. M. Viller, Paris 1932-1995, t. IV, s. 590-594.

11 Por. J.K. MiczyŃski, La cristologia esistenziale nell'esperienza e nella dottrina di Elisabetta della Trinità, Roma 2005, s. 48.

12 C. De Meester, Deux poésies inédites, s. 35.

13 Tekst francuski został zaczerpnięty z: „Carmel” 2000, nr 2, s. 41-43.
} 
4. Déjà je t'appartiens tout entière. Quand j'entrerai dans le monastère Ô mon Jésus, mon céleste Ami, Mon coeur te sera-t-il plus uni?

5. Tu sais bien, je ne vis que pour toi. Je n'aspire qu'à porter ta croix, Qu'à vivre dans ton union intime En morte, en crucifiée, en victime.

6. Bon Jésus, qu'à partir de ce jour Je sois martyre de ton amour. Seulement tu connais ma faiblesse, Soutiens-moi bien dans la détresse.

7. Mon Dieu, puisque par obéissance Je ne puis m'imposer des souffrances, Ah! Du moins brise ma volonté, Je ne veux plus de ma liberté.

8. Fais-moi tout humble, toute petite, Abaisse-moi bien à chaque instant, Car je le sais, une carmélite Doit ressembler au petit enfant.

9. Ah! que personne ne songe à moi Et que moi je ne pense qu'à toi Ô Passion, ô Vie, ô Bien suprême, Qui t'es emparé de tout moi-même.

10. Vous que le monde ne verra plus! Ô soeur Madeleine de Jésus, Jouissez en cette arche bénie De la part que Dieu sous a choisie.

12. Vous vous croyez en un coin des cieux Ô novice au visage radieux, Vous voilà donc enfin prisonnière Pour consoler de Dieu solitaire.
4. Już do Ciebie należę cała.

A kiedy wstąpię do klasztoru, O mój Jezu, mój niebiański Przyjacielu, Czy me serce będzie z Tobą bardziej zjednoczone?

5. Ty wiesz dobrze, że żyję jedynie dla Ciebie, Niczego nie pragnę jak tylko niesienia Twego krzyża, Życia w Twej intymnej jedności -w śmierci, w ukrzyżowaniu, w ofierze.

6. Dobry Jezu, obym począwszy od tego dnia Była męczennicą Twojej miłości, Tylko Ty znasz moją słabość, Podtrzymaj mnie mocnow [moim] zmartwieniu.

7. Mój Boże, skoro przez posłuszeństwo Nie mogę nakładać na siebie cierpień, Ach! Przynajmniej skrusz moją wolę. Nie chcę już więcej mojej wolności.

8. Uczyń mnie całkowicie pokorną, całkowicie małą, Uniż mnie mocno w każdym momencie. Wiem bowiem o tym, że karmelitanka Winna być podobna do małego dziecka.

9. Ach! Niech nikt o mnie nie rozmyśla, I obym ja myślała jedynie o Tobie, O Pasjo, o Życie, o Dobro najwyższe, Które opanowujesz mnie całą.

10. Ty, której świat już więcej nie dosięga! O siostro Magdaleno od Jezusa, Raduj się w tej błogosławionej arce Tą cząstką, którą Bóg wybrał tobie.

11. Tyś zaufała rąbkowi nieba, Nowicjuszko o promiennym obliczu, Otoś zatem w końcu uwięziona, By pocieszać Boga samotnego. 
13. Ah! faites une bonne prière

Pour les postulantes du Carmel

Qui ne pouvent répondre à l'appel

Divin, et partir au monastère.

14. E puis, toutes ensemble, ô mes soeurs,

Rendons grâces à Notre Seigneur

Pour cette part qu'Il nous a choisie:

Ah! qu'elle est belle et digne d'envie.
13. Ach! Pomódl się mocno

Za postulantki Karmelu

Które nie mogą odpowiedzieć na wezwanie

Boże i wstąpić do klasztoru.

14. I w końcu wszystkie razem, o moje siostry, Wznieśmy dziękczynienie naszemu Panu Za tę cząstkę, którą On nam wybrał: Ach! Jak ona jest piękna i godna zazdrości.

W wierszu można dostrzec wielką liczbę apostrof; skierowane są one do przywdziewającej habit karmelitanki, do innych sióstr, a przede wszystkim do Chrystusa. Elżbieta określa Go na wiele sposobów:

- moja Pasja (ma Passion),

- mój Boży Oblubieniec (mon divin Époux),

- moja Miłość (mon Amour),

- mój najdroższy Skarb (mon bien cher Trésor),

- moje Życie ( $m a$ Vie),

- moje Dobro najwyższe (mon Bien suprême),

- mój niebiański Przyjaciel (mon céleste Ami),

- dobry Jezus (bon Jésus).

Wszystkie te określenia (wzmocnione zaimkiem dzierżawczym „mój”) są dowodem intensywności uczuć Elżbiety względem Syna Bożego, wskazują na wielowymiarowość tej relacji, a tym samym mówią o szczególnym działaniu łaski Bożej w jej sercu. I chociaż w wierszu można odnaleźć także ogólne odniesienia do Boga (np. mon Dieu, mój Boże), widać wyraźnie, że oś relacji ze Stwórcą stanowi oblubieńcza miłość do Chrystusa.

Na podstawie tego utworu można sądzić, że dziewiętnastoletnia Elżbieta jest mocno przekonana o swoim powołaniu. Rozumie je głęboko - jako oderwanie serca od niewłaściwych przywiązań do świata. Tęskni za przejściem na drugą stronę klauzury, ale rozumie je jako tylko dopełnienie tego, co już zaczyna się dokonywać w jej duszy - jako uzupełnienie zjednoczenia w głębi serca. Ilustruje to pytaniem retorycznym w strofie 4 :

Już do Ciebie należę cała.

A kiedy wstąpię do klasztoru,

O mój Jezu, mój niebiański Przyjacielu,

Czy me serce będzie z Tobą bardziej zjednoczone? 
Na wezwanie Chrystusa Elżbieta pragnie odpowiedzieć: posłuszeństwem, skruszeniem, wyrzeczeniem się własnej woli, uniżeniem, pokorą, stanięciem się jak dziecko, wyznaniem własnej słabości, a także pocieszaniem Go, przyjmowaniem dla Niego cierpień, niesieniem Jego krzyża. Widać w tej postawie między innymi wpływ duchowości karmelitańskiej, a także francuskiej pobożności XIX wieku (idea pocieszania Chrystusa) oraz neoplatonizmu (strofa 11: postrzeganie Boga jako samotnego ${ }^{14}$ ).

Interesujące jest to, że Elżbieta jeszcze przed wstąpieniem do klasztoru określała karmelitanki z Dijon jako „moje siostry” ( mes soeurs, strofa 13). Być może wynikało to $z$ wielkiej uczuciowości ${ }^{15}$, ale wydaje się, że także $z$ tego, iż świadomie się z nimi wewnętrznie identyfikowała, uważając się za postulantkę duchową. Potwierdzają to kolejne wersety tej samej strofy: „Wznieśmy dziękczynienie naszemu Panu / Za tę cząstkę, którą On nam wybrał”.

Analizując treść P 72 bis, warto dostrzec biblijną metaforę arki (strofa 10), której w tym wierszu nadano nowe znaczenie. Ukrycie się wewnątrz arki przed potopem to obraz wstąpienia za kraty karmelu, schronienia się przed zalewającymi świat przyziemnymi rozrywkami ${ }^{16}$. Nie znaczy to, że Elżbieta nie kochała swoich bliskich (strofa 3); miała jednak świadomość, że Bóg wybiera dla niej inne miejsce. Starała się iść drogą posłuszeństwa. $Z$ tego też powodu pisze w strofie 7 , że nie może na siebie nakładać dodatkowych cierpień; taki nakaz otrzymała prawdopodobnie od któregoś ze spowiedników.

Swoje oczekiwanie na wstąpienie do karmelu, co ostatecznie miało miejsce 2 sierpnia 1901 roku, Elżbieta uczyniła aktem miłości. Był to dla niej czas trudu, ale - przez to - także duchowego wzrostu. W tym czasie Pan Bóg kształtował ją tak, by tęskniła przede wszystkim za zjednoczeniem z Nim w głębi swojego serca.

14 Myśl o pocieszaniu samotnego Chrystusa ma także oparcie biblijne; jest odpowiedzią na ewangeliczny opis opuszczenia Go przez uczniów podczas modlitwy w Getsemani, a także w czasie męki i konania na krzyżu. Natomiast rozważając to wyrażenie (o Bogu samotnym) na płaszczyźnie filozoficznej, trzeba stwierdzić w świetle wspólcześnie rozwiniętego personalizmu, że Bóg nie jest samotny, ale jest Komunią Osób (Trójcą Swiętą), która jednoczy się z osobami przez Nią stworzonymi.

15 W wierszu można dostrzec wiele wykrzykników - westchnień i zawołań.

16 Takie lekko negatywne widzenie świata u młodej Elżbiety mogło być spowodowane wpływem jansenizmu albo zmaganiem $z$ własną naturą, albo też głębokim światłem mistycznym, dającym przekonanie o nieporównanie większej wartości rzeczy nieprzemijających względem - nawet Bożych - radości doczesnych. 


\section{Pragnienie zjednoczenia z Bogiem mieszkającym w sercu - WIERSZ P 72 TER}

Jak zauważa o. De Meester, drugi odnaleziony młodzieńczy wiersz Elżbiety Catez (P 72 ter), napisany 16 grudnia 1899 roku, oddycha tym samym klimatem modlitwy, a w jego treści - podobnie jak poprzednio - pojawia się kwestia wstąpienia do karmelu (strofa 10), ale bardzo dyskretnie ${ }^{17}$. Tym razem tematem wiodącym jest utworzenie w sercu celi - mieszkania i rozmównicy dla Jezusa (strofy 1-2), oraz zjednoczenie z Nim. O. De Meester twierdzi, że chociaż idea zamieszkiwania Boga w człowieku była Elżbiecie znana, niemniej samo określenie „cela” (cellule, strofa 1$)^{18}$ przejęła ona ze słownictwa karmelu w Dijon, który opierał się często na nauczaniu dominikanina o. Valléego (1841-1927). Ten zaś prawdopodobnie inspirował się św. Katarzyną ze Sieny (1347-1380), która podzieliła się tym obrazem ze swoim spowiednikiem - Rajmundem z Kapui (1330-1399) ${ }^{19}$. Należy się z tą opinią zgodzić, ale trzeba jednocześnie zauważyć, że Elżbieta spotkała się z o. Valléem po raz pierwszy osobiście dopiero w następnym roku kalendarzowym $-1900^{20}$.

Również i w tym utworze można dostrzec, jak intensywne uczuciowo byto odniesienie autorki do Chrystusa; nazywa Go wieloma imionami - łącząc je z przymiotnikami bądź zaimkami:

- moja Miłość (mon Amour),

- moje Życie (ma Vie),

- umiłowany Zbawiciel (bien-aimé Sauveur),

-Zbawiciel Boski (divin Sauveur),

- moja Pasja (ma Passion),

- mój Skarb (mon Trésor),

- mój Oblubieniec (mon Époux),

- mój Król (mon Roi),

- mój Mistrz (mon Maitre),

- Pan (Seigneur).

17 Zob. C. De MeEster, Deux poésies inédites, s. 37-38.

18 Por. ZD 5 (ok. 23 stycznia 1900): „[... ] Ofiaruję Ci celkę mego sera, niech to będzie Twoja mała Betania; przychodź, by tam odpoczywać, ja tak bardzo Cię kocham..."; por. Dzk 140 (z 24 stycznia 1900): ,[... ] Niech w ciągu tych błogosławionych dni żyję w najpełniejszym zjednoczeniu z Tobą, niech żyję tylko wewnątrz, w tej celce, którą Ty budujesz w moim sercu".

19 C. De MeEster, Deux poésies inédites, s. 38.

20 Zob. Annexe I. Renseignements divers sur Élisabeth et son Carmel, w: ÉLISABETH DE LA TRINITÉ, CEuvres complètes, s. 1069. 
Wiersz ten - wydaje się - tchnie jeszcze bardziej Bożym pokojem, cierpliwością i akceptacją. Elżbieta w konieczności oczekiwania widzi Boży plan (strofa 10). Można dostrzec, że jej duchowy wzrost następuje szybko. Autorka prosi Chrystusa, by codzienne zajęcia, rozrywki, przyjemności i radości nigdy nie odłączyły jej od Niego (strofa 9). Jej największym bowiem pragnieniem jest być całkowicie zjednoczoną w miłości ze Zbawicielem. W tym miejscu zacytujmy utwór w całości ${ }^{21}$, dodając jedynie informację, że według Conrada De Meestera jego część centralną stanowią strofy 4-9; uwaga Elżbiety ogniskuje się tu nie na wewnętrznej celi (cellule), ale właśnie na zjednoczeniu (l'union) $z$ Jezusem ${ }^{22}$.

\section{Union de l'âme à Notre Seigneur}

1. Jésus, mon Amour et ma Vie, Daigne m'aider je t'en supplie

À bâtir, bien-aimé Sauveur,

Une cellule dans mon coeur.

2. Ce sera ton petit parloir, Humble et bien modeste demeure Où je serai sûre à toute heure De te trouver et de te voir.

3. Là, dans le calme et la silence, Je jouirai de ta présence Et m'abandonnant tout à toi J'écouterai parler ta voix.

4. Ah! prends-moi, prends-moi tout entière, Je suis tienne, divin Sauveur. Enlève, arrache de mon coeur Ce qui le retient à la terre.

5. Que rien ne vienne me distraire De toi, ni troubler notre union. Pardonne-moi si solitaire Je te laisse, ô toi ma Passion.

\section{Zjednoczenie duszy z naszym Panem}

1. Jezu, moja Miłości i moje Życie, Racz pomóc mi, proszę Cię o to, Utworzyć, umiłowany Zbawicielu, Celę w moim sercu.

2. Będzie ona Twoją małą rozmównicą, Pokornym i bardzo skromnym mieszkaniem, Gdzie będę pewna w każdej godzinie Odnaleźć Ciebie i Ciebie zobaczyć.

3. Tam, w spokoju oraz cichości, Rozraduję się z Twej obecności, I powierzając się Tobie cała, Twojego głosu będę słuchała.

4. Ach, weź mnie, weź mnie całą, Jestem Twoją, Zbawicielu Boski, Wydobywam, wyrywam $z$ mego serca To, co przytrzymuje je na tej ziemi.

5. Niech nic nie przyjdzie mnie odłączyć Od Ciebie ani zakłócié naszą jedność. Przebacz mi, tak samotny, Opuszczam Ciebie, o Ty - moja Pasjo.

21 Tekst francuski został zaczerpnięty z: „Carmel” 2000, nr 2, s. 43-44.

22 C. De Meester, Deux poésies inédites, s. 38. 
6. Fais-moi bien humble, bien petite,

Bâtis en moi la carmélite,

Cette âme qui ne vit qu'en toi

Son Trésor, son Époux, son Roi.

7. Tu le sais, ma consolation

C'est de vivre dans [ton] union.

Qu'elle grandisse, je t'en prie,

Àchaque moment de ma vie.

8. Je te répète, prends-moi,

Prends-moi, mon Maitre, je suis tienne.

Absorbe-moi si bien en toi

Que tout mon être t'appartienne.

9. Seigneur, que mes occupations,

Que les fêtes, les distractions,

Les plaisirs, les joies de la terre

De toi ne puissent me distraire.

10. Lorsque tu jugeras l'attente

De ta petite postulante

Assez longue, ô mon Dieu, mon Roi,

Prends-moi, j’attends, je suis à toi.
6. Uczyń mnie bardzo pokorną, bardzo małą, Utwórz we mnie karmelitankę, Tę duszę, która żyje jedynie w Tobie Jej Skarbie, jej Oblubieńcu, jej Królu.

7. Ty to wiesz, moim pocieszeniem jest życie w jedności z Tobą.

Niech ona wzrasta, proszę Cię o to,

W każdej chwili mego życia.

8. Powtórzę Tobie, weź mnie,

Weź mnie, mój Mistrzu, jestem Twoja.

Wchłoń mnie tak mocno w siebie,

By całe moje istnienie należało do Ciebie.

9. Panie, oby moje zajęcia,

Oby święta, rozrywki,

Przyjemności, radości tej ziemi,

Nie mogły odłączyć mnie od Ciebie.

10. Kiedy uznasz oczekiwanie

Twojej małej postulantki

Za wystarczająco długie, mój Boże, mój Królu,

Weź mnie, ja czekam, jestem dla Ciebie.

Trzeba zauważyć, że Elżbieta jeszcze przed rozpoczęciem życia zakonnego miała przeświadczenie, że jedność z Bogiem polega na tajemnicy zamieszkania: Boga w człowieku (strofy 1-3) oraz człowieka w Bogu (strofy 6-8). Można przypuszczać, że doświadczała w tym okresie pierwszych darów mistycznych (albo ich zapowiedzi) - modlitwy odpocznienia, modlitwy skupienia wewnętrznego. Znamienne jest uznanie przez nią prymatu łaski. Swiadczą o tym słowa strofy 6: „Uczyń mnie bardzo pokorną, bardzo małą, / Utwórz we mnie karmelitankę".

Cechą charakterystyczną wewnętrznej postawy Elżbiety było to, że potrafiła całą swoją naturę ( $z$ wszystkimi uwarunkowaniami) ukierunkować na Boga. Łaska zaś tę naturę wydoskonalała, oczyszczała i uświęcała. W ten sposób tworzyła się pomiędzy nimi silna więź. 


\section{Pragnienie jako ogniwo silnej więzi z Bogiem}

Idąc śladem o. De Meestera, trzeba stwierdzić, że chociaż oba wiersze są napisane językiem prostym, wykorzystującym niewielką liczbę słów, ich treść jest bardzo głęboka i teologicznie intensywna. Podobne wyrażenia można dostrzec również w innych pismach Elżbiety z tego okresu; na przykład w listach Le 25-26 (do Marii Luizy Maurel z 29-30 listopada 1899 roku oraz z początku stycznia 1900 roku), w końcowej części Dziennika (Journal), w Zapiskach duchowych 4-5 (Notes intimes), w pozostałych wierszach młodzieńczych. Wszystkie cechuje ten sam wewnętrzny pokój oraz wyrażana w nich bezwarunkowa miłość do Chrystusa ${ }^{23}$.

Można powiedzieć, że wiersze P 72 bis oraz $\mathrm{P} 72$ ter są swego rodzaju zwieńczeniem pierwszej części drogi życia wewnętrznego Elżbiety - świadectwem tego, co się już w niej dokonało, i jej otwartości na to, co przygotowała dla niej Boża Opatrzność. Kończący się etap (czas przebywania w świecie) można zobrazować na podstawie jej młodzieńczych pism następującą tabelką, która ukazuje działanie łaski Bożej w duszy Elżbiety oraz jej aktywną postawę wobec Boga.

\begin{tabular}{|c|c|c|}
\hline & ŁASKA Jezusa & $\begin{array}{c}\text { Skutki tejłaski } \\
\text { oraz ODPOWIEDŹ Elżbiety }\end{array}$ \\
\hline $\begin{array}{c}1 \\
\text { rok życia, } \\
\text { dzieciństwo }\end{array}$ & Dar życia i chrztu św. & $\begin{array}{l}\text { Modlitwa prośby za innych - do } \\
\text { „dobrego Jezusa” (por. Le 1); czas nauki } \\
\text { katechizmu, modlitw, pierwsze chwile } \\
\text { spędzane na nabożeństwach liturgicz- } \\
\text { nych }\end{array}$ \\
\hline $\begin{array}{c}7 \\
\text { rok życia }\end{array}$ & $\begin{array}{l}\text { Pierwsza spowiedź } \\
\text { (doświadczenie Bożego } \\
\text { miłosierdzia) }\end{array}$ & $\begin{array}{l}\text { Zmiana postawy - charakteru } \\
\text { (Souvenirs, 6), chęć pracy nad sobą } \\
\text { i pragnienie bycia zakonnicą (na razie } \\
\text { tylko ogólne-bez wskazywania kon- } \\
\text { kretnego zgromadzenia; Souvenirs, 17), } \\
\text { staranne przygotowanie się do Pierwszej } \\
\text { Komunii Świętej }\end{array}$ \\
\hline $\begin{array}{c}11 \\
\text { rok życia }\end{array}$ & Pierwsza Komunia Święta & $\begin{array}{l}\text { Otwartość serca, przyjmowanie miłości } \\
\text { Bożej, odkrywanie wewnętrznej obec- } \\
\text { ności Jezusa, doświadczanie Boga } \\
\text { (P 47, Ppol 48) }\end{array}$ \\
\hline
\end{tabular}

23 Por. tamże, s. 40. 


\begin{tabular}{|c|c|c|}
\hline \multirow[t]{2}{*}{$\begin{array}{c}14 \\
\text { rok życia }\end{array}$} & $\begin{array}{l}\text { Zaproszenie, by poświęcić } \\
\text { się całkowicie Bogu }\end{array}$ & $\begin{array}{l}\text { Ślub czystości, czyli pełne oddanie sie } \\
\text { w ręce Zbawiciela (Souvenirs, 18-19) }\end{array}$ \\
\hline & $\begin{array}{l}\text { Usłyszenie na modlitwie } \\
\text { słowa „Karmel” } \\
\text { (Souvenirs, 19) }\end{array}$ & $\begin{array}{l}\text { Pragnienie bycia karmelitanká, Jego ob- } \\
\text { lubienicą, poznanie Jego osoby poprzez } \\
\text { rozważanie Jego męki; odkrycie, że } \\
\text { Jezus za nią umarł; dlatego i ona pragnie } \\
\text { odtąd cierpieć dla Niego; kontemplacja } \\
\text { i fascynacja ukrzyżowaną miłością } \\
\text { Jezusa; pragnienie wspótcierpienia } \\
\text { z Nim i oddania Mu swojego życia, } \\
\text { by Go pocieszać }\end{array}$ \\
\hline $\begin{array}{c}16 \\
\text { rok życia }\end{array}$ & \multirow{5}{*}{$\begin{array}{l}\text { Łaska oczyszczenia } \\
\text { (cierpienie spowodowane } \\
\text { oczekiwaniem na wstąpie- } \\
\text { nie do klasztoru) } \\
\text { - Jezus jakby oddalony; } \\
\text { początkowo brak perspek- } \\
\text { tyw na zrealizowanie } \\
\text { powołania, które dał Bóg }\end{array}$} & Początkowo - łzy i ból \\
\hline \multirow[t]{3}{*}{$\begin{array}{c}17 \\
\text { rok życia }\end{array}$} & & $\begin{array}{l}\text { Akceptacja cierpienia i ofiarowanie } \\
\text { go za grzeszników; fascynacja Chrystu- } \\
\text { sowym krzyżem prowadzi Elżbietę } \\
\text { do pragnienia ofiarowywania się } \\
\text { za grzeszników (pierwszy raz wP } 32, \\
\text { Ppol 33); pragnienie pocieszania } \\
\text { Jezusa (tamże) }\end{array}$ \\
\hline & & $\begin{array}{l}\text { Akceptacja cierpienia jako pragnienie } \\
\text { pełnienia woli Jezusa - woli Bożej }\end{array}$ \\
\hline & & $\begin{array}{l}\text { Pragnienie cierpienia jako środka, } \\
\text { by się upodobniać do Jezusa (odkry- } \\
\text { cie cierpienia jako wartości - narzędzia, } \\
\text { które formuje w duszy obraz Zbawicie- } \\
\text { la). Pragnienie zjednoczenia woli z wolą } \\
\text { Jezusa (P 44, 53, Ppol 45, 54) }\end{array}$ \\
\hline \multirow[t]{2}{*}{$\begin{array}{c}18 \\
\text { rok życia }\end{array}$} & & $\begin{array}{l}\text { Szukając oparcia, wspomina otrzymane } \\
\text { już w życiu łaski, które są niejako } \\
\text { „fundamentami” jej relacji z Jezusem. } \\
\text { Tym samym w chwili próby odwołuje się } \\
\text { do swojego wewnętrznego doświadcze- } \\
\text { nia, które wcześniej otrzymała (P } 47 \text {, } \\
\text { 51, Ppol 48, 52). Odtąd pragnie budo- } \\
\text { wać całe życie tylko na słowie Jezusa } \\
\text { (P 51, Ppol 52) }\end{array}$ \\
\hline & $\begin{array}{l}\text { Dar odczuwania } \\
\text { pragnienia cierpienia } \\
\text { (P 55. Ppol 56) }\end{array}$ & $\begin{array}{l}\text { Odkrycie cierpienia jako daru od Jezusa } \\
\text { dla tych, których kocha (P 55; por. P 59, } \\
\text { Ppol 56; por. P 60) }\end{array}$ \\
\hline
\end{tabular}




\begin{tabular}{|c|c|c|}
\hline \multirow[t]{2}{*}{$\begin{array}{c}19 \\
\text { rok życia }\end{array}$} & $\begin{array}{l}\text { Rozmowa z Jezusem } \\
\text { w czasie rekolekcji - } \\
\text { Elżbieta słyszy Jego słowa } \\
\text { mówiące o tym, że wysłu- } \\
\text { chał jej prośby, by mogła } \\
\text { cierpieć dla Niego; } \\
\text { dlatego chce On, by dzie- } \\
\text { liła z Nim krzyż (P 66, } \\
\text { Ppol 67). Łaska nowej } \\
\text { jedności z Jezusem, której } \\
\text { wcześniej w takim stopniu } \\
\text { nie doświadczała (P 66, } \\
\text { Ppol 67), i coraz większego } \\
\text { głodu Boga (CEuvres, } \\
\text { 804-805); modlitwa od- } \\
\text { pocznienia (J 14, Dzk 14) }\end{array}$ & $\begin{array}{l}\text { Wzmożona praca nad charakterem. } \\
\text { Czuje sie oblubienicą Chrystusa } \\
\text { i Jego ofiarą-żertwą. Dla Jezusa pragnie } \\
\text { nieść ciężar grzechów świata (J 7, Dzk 7) }\end{array}$ \\
\hline & $\begin{array}{l}\text { Łaska dostrzeżenia złości } \\
\text { własnych grzechów } \\
\text { (J 39, Dzk 39); działanie } \\
\text { Boże zabierające strach } \\
\text { przed sądem Bożym } \\
\text { (J 37, Dzk 37) }\end{array}$ & Spowiedź generalna \\
\hline
\end{tabular}

Elżbieta poznaje miłość Jezusa wcześniej, niż pozna głębiej prawdę o tym, że On za nią osobiście umarł na krzyżu. Doświadczenie miłości wyprzedza czasowo intelektualne poznanie prawdy o Zbawicielu. Najpierw - jako dziewczynka - poznaje dobroć i bliską obecność Chrystusa, a następnie pogłębia wiedzę, kim On jest. Kontemplując pasję Chrystusa, Elżbieta stopniowo odkrywała rolę swojego osobistego cierpienia; dostrzegała coraz wyraźniej, że służy ono:

- oderwaniu się od swoich planów, od świata,

- zdaniu się tylko na Boga,

- poznaniu cierpiącego Jezusa,

- zjednoczeniu się z Nim,

- ofiarowaniu się za grzeszników,

- upodobnieniu się do Jezusa.

W młodzieńczym życiu Elżbiety można dostrzec dynamikę spotykania się dwóch światów - misterium jednoczenia się Jezusa i przyszłej karmelitanki. Wraz z coraz głębszym poznaniem Chrystusa idzie w parze rosnące przekonanie, że On ma nad wszystkim kontrolę. Wszystkie chwile przeżyte z Nim prowadzą do głębszej jedności. Na przykład Elżbieta, poznając ból i osamotnienie 
Jezusa, widzi, że jej własne osamotnienie (spowodowane m.in. niespełniającym się pragnieniem) prowadzi do tego, by mogła bardziej poznać Jego - to, co On przeżywał. Wszystko po to, by jednocząc się z Nim, ofiarować Mu wszystko dla zbawienia innych. Gdy zaś Elżbieta widzi Jezusa cierpiącego, odkrywa jednocześnie, że cierpienie przeżyte $z$ miłością kształtuje w niej obraz Zbawiciela i pozwala jej stać się bardziej podobną do Niego.

Punktem spotkania z Jezusem stają się więc wszystkie momenty jej życia. Dają one możliwość doświadczania Go ciagle w nowy sposób - osobiście. Elżbieta nie robi kroków wstecz; w swoich Zapiskach duchowych notuje: „Jeśli nigdy się nie poprawiam, och, zaklinam Ciebie, proszę Cię o to, wówczas, gdy jestem cała Twoja, weź mnie, przypraw mnie o śmieré” („Si jamais je [me] reprends, oh, je t'en conjure, je t'en supplie: pendant que je suis tout à toi, emmène-moi, fais-moi mourir"; por. ZD 5).

Wiersze $\mathrm{P} 72$ bis i $\mathrm{P} 72$ ter napisane zostały pod koniec tego procesu - drogi oczyszczenia czynnego (nocy czynnej zmysłów i ducha). Półtora roku później Elżbieta natomiast ujawni w liście (Le 53 z 8 maja 1901 roku do Małgorzaty Gollot), że na krótko przed wstąpieniem do klasztoru rozpoczą się w jej życiu wewnętrznym nowy etap - nocy biernej. Ujmie to w następujących słowach: „[... ] módl się bardzo za mnie. Mnie również już nie zasłona, lecz jakiś bardzo gruby mur Go [Jezusa] zakrywa. Czy nie uważasz, że jest to bardzo ciężkie po tym, gdy się Go czuło tak blisko? Ale jestem gotowa trwać w takim stanie duszy tak długo, dopóki będzie się podobało memu Umiłowanemu mnie w nim zostawić $[\ldots]$. On wie doskonale, że teraz zbyt mocno Go miłujemy, żeby Go opuścić" (Le 53).

Podsumowując, można stwierdzić, że taką wewnętrzną postawę (zapisaną w P 72 bis oraz P 72 ter) Elżbieta mogła przyjąć przede wszystkim dzięki działaniu łaski - dzięki pragnieniom, które Bóg wlał w jej serce, a które budziły tęsknotę:

- za Nim samym,

- za wstąpieniem do karmelu,

- za pogłębianiem jedności z Jezusem-Oblubieńcem (poprzez poznawanie Go, pocieszanie, współcierpienie, trwanie we wzajemnej miłości).

W kolejnych latach swojego życia Elżbieta będzie kontynuować tę drogę. Wsłuchana w głos Ducha Świętego, poznając słowo Boże zapisane w Biblii oraz głos Kościoła, będzie odkrywać misterium zamieszkania Trójcy Swiętej w człowieku usprawiedliwionym, a także pogłębiać więź z Chrystusem na płaszczyźnie wiary, nadziei, miłości, wierności, zaufania, ubóstwa ducha, pokory, czystości, ofiary, wewnętrznego wyciszenia, cierpienia i uwielbienia. Wówczas również na nowo odkryje bogactwo relacji z Maryją i zbawionymi w niebie - w tajemnicy świętych obcowania. Zacznie coraz bardziej tęsknić za życiem w niebie, które $\mathrm{w}$ wierze rozpoczyna się już tu na ziemi. 


\begin{abstract}
JAN KRZYSZTOF MiCZYŃSKI

Theological Commentary on the Two Poems of St Elisabeth of the Trinity, Unpublished in Polish, Found and Described by Fr Conrad De Meester, OCD

The text refers to the article published in print in 2000, by Fr Conrad De Meester, OCD, entitled Two Unpublished Poems (French original: Deux poésies inédites, "Carmel" 2000, no. 2, 33-44). It is a theological commentary on two poems written by Elisabeth in her youth: $\mathrm{P} 72$ bis and $\mathrm{P} 72$ ter. She composed them before entering Carmel, toward the end of the first stage of her spiritual life, which was the path of active purification (active night of the senses and spirit). Elisabeth expresses her longing for God, for entering Carmel, for being entirely united to Jesus, her Beloved, and configured to Him. These desires, with the help of God's grace, will become a firm foundation for the relationship with God and will allow her to take the path toward holiness.
\end{abstract}

Słowa klucze: św. Elżbieta, pragnienie, zjednoczenie, poezja

Keywords: St Elisabeth, desire, union, poetry 